\title{
Re-envisioning the Role of Universities in Early Childhood Teacher Education: Community Partnerships for 21st-Century Learning
}

Amy J. Heineke

Loyola University Chicago, aheineke@luc.edu

Adam S. Kennedy

Loyola University Chicago, akenne5@luc.edu

Follow this and additional works at: https://ecommons.luc.edu/education_facpubs

Part of the Education Commons

\section{Author Manuscript}

This is a pre-publication author manuscript of the final, published article.

\section{Recommended Citation}

Heineke, Amy J. and Kennedy, Adam S.. Re-envisioning the Role of Universities in Early Childhood Teacher Education: Community Partnerships for 21 st-Century Learning. Journal of Early Childhood Teacher Education, 35, 3: , 2014. Retrieved from Loyola eCommons, Education: School of Education Faculty Publications and Other Works, http://dx.doi.org/10.1080/10901027.2014.936072

This Article is brought to you for free and open access by the Faculty Publications and Other Works by Department at Loyola eCommons. It has been accepted for inclusion in Education: School of Education Faculty Publications and Other Works by an authorized administrator of Loyola eCommons. For more information, please contact ecommons@luc.edu.

\section{(c) $($ () $\ominus$}

This work is licensed under a Creative Commons Attribution-Noncommercial-No Derivative Works 3.0 License. (c) National Association of Early Childhood Teacher Educators, 2014. 
Re-envisioning the Role of Universities in Early Childhood Teacher Education:

Community Partnerships for 21st Century Learning

\begin{abstract}
Despite contrasting views on the overlap of early childhood education and teacher education, opportunities abound for expanding the role of early childhood educators in broader teacher education discourse. University-based early childhood and Kindergarten-through-grade-12 teacher education share purposes, philosophies, and resources that should be explored to more effectively address the needs of diverse young children and their families. Community partnerships and a shift toward community-based teacher preparation present a context and opportunity for exploring the overlap of these two historically separate fields. In this paper, we present a framework for collaborative, field-based early childhood teacher preparation, situating birth-though-grade-12 teacher education in diverse community contexts and involving school and community personnel to achieve universal $21^{\text {st }}$ century goals for the teaching and learning of young children.
\end{abstract}

\title{
Introduction
}

Renewed calls for the reform of teacher preparation have emerged in recent years, leading to an increased focus on the redesign of traditional teacher education programs (Ball \& Forzani, 2009), a direct result of the failure of teacher education to link theory, preparation, and practice to the contexts and continuum of teachers' professional lives (AACTE, 2010; Rust, 2010) and the simultaneous increase in for-profit and fast-track teacher credentialing programs (Feistritzer, 2007; Larabee, 2010). To support the development and achievement of learners in contemporary classrooms, teacher education must prepare candidates for schools that are increasingly characterized by diversity, innovative instructional technologies, globalized goals, and other $21^{\text {st }}$ century challenges (Zhao, 2010). Due to these key shifts in educational policy and practice, teacher education is in the midst of a shift in focus from university-based preparation of individual teachers with a goal of placement and retention in schools (Freedman \& Appleman, 2009) to authentic preparation of teachers to be engaged and committed to learning through teaching, and a broadened 
impact on not only children and schools, but families and communities as well (Darling-Hammond \& Baratz-Snowden, 2004).

The intersection of teacher education and early childhood education remains underrepresented in teacher education research and policy, as evidenced by the Kindergartenthrough-grade-12 (K-12) focus of nearly all of these calls for reform (Hatch \& Benner, 2009). The need and opportunity for expanding the role of early childhood educators in the broader teacher education discourse are great, given that their voices have been largely absent from conversations regarding the need for innovative teacher preparation. In fact, the challenges of addressing the needs of diverse children within a reform-based climate of increasingly rigorous learning standards require better alignment of preparation practices and collaboration across early childhood and K-12, or the birth-through-grade-12 (B-12) continuum. This alignment reflects a recognition that these challenges may be too great for either K-12 or early childhood educators to face in isolation; a parallel argument may be made with regard to teacher educators as well (Beyer \& Davis, 2008; Blank, 2010). Discussions about aligning early childhood and K-12 education practices have primarily focused on the role of schools in adapting practices and influencing policy, namely by aligning best practices across early childhood and elementary settings (e.g., P-3 and P-12 initiatives; Center for the Study of Education Policy, 2012; Demma, 2010). To ensure that young children maintain developmental gains from preschool and succeed throughout elementary school and beyond, early childhood professionals must certainly be prepared to participate as equal partners in blending these traditionally separate educational sectors (Center for the Study of Educational Policy, 2012). Teacher preparation programs can play a significant role in addressing a seamless learning continuum that aligns early childhood and early elementary practices; however, the precise responsibilities of teacher educators in both modeling this form of collaboration and teaching its associated knowledge and skills to teacher candidates remain unexplored in current teacher education literature. 
Through recent efforts to re-envision initial teacher certification programs at our university, we recognize the necessity to utilize the strengths from both early childhood and K-12 teacher education programs, as well as the rich resources of schools and communities. In this way, early childhood education faculty, K-12 teacher education faculty, and school and community leaders collaborate to prepare well-equipped teachers who are able to meet the needs of diverse learners in B-12 educational settings that feature seamless systems of support across the developmental continuum. Based upon the complete redesign of our university-based early childhood and K-12 teacher education programs, we present a framework for collaborative, field-based early childhood teacher preparation that includes university, school, and community personnel in efforts to achieve shared goals. We begin by outlining contemporary demands for teachers and framing the context of early childhood and teacher education. We then share an example of early childhood teacher preparation in collaboration with B-12 community settings that is grounded in the notion that every educator must be knowledgeable of the developmental continuum and skilled in addressing the needs of diverse populations. We close with a discussion of collaboration, as the program exemplifies how typically separate educational stakeholders can converge, allowing teacher education and early childhood education to informing one another.

\section{The Changing Context of Teacher Education}

Teacher education is in the midst of a shift in focus from university-based preparation of individual teachers with a goal of placement and retention in schools to more authentic preparation of teachers who are deeply engaged with their profession and who are committed to learning through teaching and to a broadened impact on children, schools, and communities (DarlingHammond \& Baratz-Snowden, 2004). This call for fundamental change to teacher preparation stems from past failures of teacher education to link theory, preparation, and practice to the contexts and continuum of teaching (American Association of Colleges for Teacher Education, 2010; Rust, 2010), 
as well as the rise of accelerated and alternative paths to teaching certification that has dichotomized and stigmatized traditional paths and institutions of teacher education (Feistritzer, 2007; Larabee, 2010). In order to support the development and achievement of learners in contemporary classrooms, faculty in teacher preparation programs must revisit and revamp their practice to prepare candidates for schools that are increasingly characterized by student diversity, innovative instructional technologies, and globalized goals and other ' $21^{\text {st }}$ century' challenges.

\section{1st Century Teaching and Learning}

In 2010, the American Association of Colleges for Teacher Education (AACTE) outlined a set of $21^{\text {st }}$ century skills to prepare students for the complexities of life and work environments. Among the skills recognized as universal across the developmental continuum are critical thinking and problem solving, communication, collaboration, and creativity/ innovation (Hatch \& Benner, 2009). Through learning to apply these skills in a variety of contexts, students become (a) critical thinkers who think outside the box to solve unfamiliar problems, (b) communicators who clearly articulate ideas, (c) collaborators who work effectively and respectfully with diverse team members, and (d) creative innovators who design and implement new and worthwhile ideas and technologies (AACTE, 2010). These $21^{\text {st }}$ century skills are critical to the continued relevance and effectiveness of university-based teacher preparation programs as they evolve to address the changing needs of the candidates and schools they serve. The 2010 recommendations echo AACTE's 2004 white paper, in which recommendations for $21^{\text {st }}$ teacher education included preparation for early childhood educators in utilizing technology as a way to adapt practice to meet the changing needs of young children. In fact, AACTE (2004) presents the need for high-quality early childhood teacher preparation as a matter of social justice, with access to degreed, credentialed, skilled, and resilient teachers as a basic right for every young child. 
The challenge of addressing this need must be met within a $21^{\text {st }}$ century context of increased student diversity across the developmental continuum. To prepare teachers for the diversity of classrooms, teacher education programs must emphasize knowledge and skills for culturally and linguistically diverse populations (AACTE, 2004; 2010) with an emphasis on the rich and unique funds of knowledge (Moll \& Gonzalez, 1997) that students and families bring to the instructional setting, as well as how to support young children's development and achievement (Wrigley, 2000). Further, teachers need to provide seamless systems of support for all children and families both within and across the many transitions children experience between B-12 (AACTE, 2004; DarlingHammond \& Baratz-Snowden, 2007; Hatch \& Benner, 2009; Hollins, 2011). This requires not only teachers, but teacher candidates, to apply AACTE's ' $21^{\text {st }}$ century skills' to challenging practical realities in alignment with local, state, and national program standards.

\section{1st Century Teacher Preparation}

Based on the array of critical competencies for $21^{\text {st }}$ century skills, scholars at the AACTE (2010) go on to identify the features that exemplary institutions must address in order to demonstrate that that their graduates are prepared with the knowledge and skills necessary to meet the needs of $21^{\text {st }}$ century learners. These include: (a) producing evidence that teacher candidates have a positive effect on students' learning; (b) preparation in differentiated instruction for all children, especially those most at risk for school failure: children with disabilities, English language learners (ELLs), and children from low-income homes; (c) extensive, in-depth clinical experiences with mentoring support, (d) practice in creating instruction aligned with curriculum standards, interpreting assessment results, and responding to students' learning needs, and (e) demonstration of cultivating a passion for teaching and learning that will support students for a lifetime and enhance educator resiliency. 
These critical competencies are universal but not comprehensive. For example, critical competencies necessary to guide effective early childhood teacher education are omitted (Hatch \& Benner, 2009). In particular, addressing the needs of caregivers and families as the context for young children's learning and development, which is a central tenet of early childhood teacher education, must be addressed within the larger context of teacher education as well given its aims to address the needs of diverse populations (Cochran-Smith, 2004; Darling-Hammond \& Baratz-Snoden, 2007; NAEYC, 2009). Nevertheless, the $21^{\text {st }}$ century skills embody goals that teacher preparation programs must aim to achieve through the redesign of teacher education programs. They are also starting points for conversations about the re-envisioning the preparation of teachers in systems of aligned B-12 practice.

\section{Current Context of Early Childhood Teacher Education}

Consistently expressed in early childhood literature over the past decade, early childhood teacher educators share the critical concern of addressing the needs of $21^{\text {st }}$ century learners (Lim \& Able-Boon, 2005). Early and Winton (2001) identified some of the key issues in the early childhood field with implications for teacher education in higher education institutions. These included increased cultural and linguistic diversity of young children and the movement to address the needs of children with disabilities in more inclusive environments, issues which are both relevant across the developmental continuum and reflected in K-12 teacher education literature. The authors also reinforced the importance of teacher preparation that addresses children's needs within the context of family and community - particularly in the case of infants and toddlers, for whom adequate preparation is lacking (AACTE, 2004).

Efforts to increase the quality of early childhood teacher preparation broadly address some of these needs. For example, increasing the number and variety of field experiences and raising expectations for entry-level teacher credentialing exemplify two approaches to meeting the growing 
need for skilled educators by enhancing their preparation (e.g., McDonald et al., 2011; Noel, 2010; Early \& Winton, 2001; Murrell, 2000). The standardization of exit assessment from teacher preparation programs using systems such as edTPA (which has to been adopted by 24 states to date) represents another of these efforts to ensure the 'readiness' of teachers to enter the field. However, the effects of such initiatives on the quality of either teacher education or teachers themselves remain unclear (Early et al., 2007), and they do little to extend the reach of early childhood into K-12 teacher education, or expand the potential for overlap. Early childhood educators require rigorous preparation for the dynamic professional responsibilities they will face as teachers. While early childhood education is distinct and requires professional preparation that differs from that of K-12 educators (NAECTE, 2009; NAEYC, 2009), the areas of overlap between early childhood and K-12 teacher education are still extensive. In particular, efforts to address early childhood teacher education program quality could be better linked to elementary and secondary educator preparation around shared goals. These include $21^{\text {st }}$ century competencies, as well as education policy and the alignment of assessment and instruction and use of evidence to support practices (AACTE, 2010; Hardman, 2009; NAEYC, 2009).

Teachers who enter the field of early childhood education face environments undergoing reform efforts and responding to changes to K-12 learning standards and their implications for the early childhood classroom. Most recently, educators across most of the United States began to utilize the Common Core State Standards as a framework and motivation for revisions of K-12 curricula, assessment materials, and teacher preparation. While implications of the Common Core for early childhood education are still under debate (e.g., Meisels, 2011), the standards movement continues to influence expectations of the youngest children, and $21^{\text {st }}$ century educators must forge stronger links among increasingly rigorous learning standards, early childhood curriculum and assessment (Fuligni, Howes, Lara-Cinisomo, \& Karoly, 2009). Without efforts in teacher education 
aimed at balancing the needs of young children with the expectations of accountability systems, novice teachers immediately experience a preparation-to-practice gap that undermines developmentally appropriate practice (Brown \& Feger, 2010; Certo, 2006). Regardless of this context of changing standards, teacher education programs must continue to prepare early childhood professionals who can both meet individual needs through developmentally appropriate practice and address national and local expectations of early childhood educators in preparing children for school. The Common Core Standards are not antithetical to early childhood education, provided serious attention is paid to: a) identifying the antecedents that lead to learners' achievement of the standards; b) reconciling these key early childhood educational and developmental milestones with curriculum scope and sequence and the principles of developmentally appropriate practice (NAEYC, 2009) and; c) collaboratively laying the groundwork for mastery when the time is ripe for young learners. In fact, this work may be viewed as a natural extension of efforts to address professional preparation and learning standards in early childhood education (e.g., birth-to-age-5 early learning standards outlined by Head Start, state boards of education and key early childhood professional organizations such as the National Association for the Education of Young Children, or NAEYC). In this sense, the Common Core presents another opportunity for the discussion of early childhood and K-12 overlap.

\section{Developing a Framework for Collaborative Teacher Preparation}

Perhaps the best opportunity for exploring the overlap between teacher education and early childhood education within a framework of $21^{\text {st }}$ century teacher competencies lies in the common goal of teacher impact beyond the classroom into schools and communities. To achieve this goal, programs must bridge the gap between preparation and practice through (a) robust, coherent, and interdisciplinary curricula that emphasize inquiry approaches to learning, (b) performance 
assessment of candidates' practice in meaningfully embedded field experiences, and (c) an overall structure grounded in strong university-school partnerships (Darling-Hammond, 2006).

Viewing teacher preparation as a vehicle for collaboratively addressing community needs, rather than relying on traditional models emphasizing foundations and methods courses with associated clinical placements, is key not only to expanding the area of intersection of early childhood and K-12, but to increasing the effectiveness of university-based programs themselves. These expectations are on the rise in early childhood; Illinois, for example, recently required early childhood educators who work in settings serving high numbers of culturally and linguistically diverse children to carry a teaching credential in English as a Second Language (ESL; Illinois \$23.111.235.20). Requirements like these reinforce the idea that $21^{\text {st }}$ century competencies require specialized preparation.

Early childhood teacher education grapples with the implications of inconsistencies in degree and certification requirements for early childhood professionals of various types (Chandler et al., 2012; NAECTE, 2009; Odom \& Wolery, 2003; Recchia et al., 2009). In fact, it has never been clearer that early childhood educators increasingly must match graduates from K-12 programs in terms of rigorous preparation. While 2-year preparation programs are common in early childhood, the competencies demanded of early childhood educators in diverse settings are less likely to be fully integrated teacher education programs which span only 2 years; furthermore, young children have a right to degreed and fully credentialed early childhood educators (AACTE, 2004). An outdated approach involving isolated packages of courses that lead to supplemental teaching endorsements reinforces a decontextualized and piecemeal approach to learning essential instructional and collaborative competencies (Authors, 2013).

For example, key scholars in ELL education reinforce that teacher preparation for cultural and linguistic diversity must be integrated across a program of study (Valdés, Bunch, Snow, Lee, \& 
Matos, 2005), rather than separated into isolated courses where learning does not extend to what teachers perceive to be a part of mainstream classroom teaching (Lucas, Villegas, \& FreedsonGonzalez, 2008). In this way, comprehensive preparation programs which integrate all of the $21^{\text {st }}$ century competencies into a meaningful context for work with diverse young children and families are sorely needed (AACTE, 2010; Authors, 2013).

Community partnerships (along with rich community-based field experiences) provide such an opportunity, where teacher education is presented with an opportunity to reflect the complex issues faced by early childhood educators and authentically integrate all of the critical competencies of teaching (Kruger, 2009). When preparation for all future teachers is itself re-envisioned beginning with nonhierarchical partnerships among university, practitioners, and the community, teacher education can reflect and embed itself in the most appropriate contexts - those in which children and families are served (Zeichner, 2010). This approach narrows the preparation-to-practice gap and affords candidates opportunities to develop communication, collaboration, critical thinking and problem solving skills authentically through teaching in settings where their creativity and innovation may be encouraged and guided. However, truly nonhierarchical partnerships must extend far beyond traditional notions of clinical placements for students at 'host' sites (Kruger, 2009).

Exclusively community-based early childhood teacher education programs remain unexplored to date; nevertheless, support for extensive supervised clinical experiences abounds, particularly in special education and early intervention literature (DEC, 2010). This integration is usually conceptualized as linking traditional coursework and field experiences or exposing teacher candidates to multidisciplinary faculty who emphasize collaboration and evidence-based strategies with research support (AACTE, 2004; 2011). Some findings suggest that clinical experiences offered in inclusive settings with sufficient support are associated with the development of more positive attitudes on the part of candidates toward their role as facilitators of inclusion (DEC, 2010; 
Leatherman \& Niemeyer, 2005). Such findings highlight the unexplored potential of field-based early childhood teacher education.

Building upon this, some contemporary early childhood educators draw from social and cultural perspectives to conceptualize early childhood teacher education as an activity that involves not only acquiring the technical and propositional knowledge of some identified standard approach, but also a recognition of the situated nature of teaching and learning and fluidity of notions about standards (Ryan \& Grieshaber, 2005). This understanding of teaching involves not only knowing the standard, but also questioning and challenging standards as socially and culturally constructed. These complex dispositions support culturally responsive practice and develop in appropriate, supported field experiences that emphasize teaching as the enactment of policy within nested systems, with influences and implications beyond the classroom (Freedman \& Appleman, 2009).

\section{Re-Envisioning Teacher Education for All Teachers}

Teaching, Learning, and Leading with Schools and Communities (TLLSC) is the collective work of (name of institution blinded for review) faculty in teacher preparation, working alongside students, community agency staff, and partners in B-12 education, motivated by a desire to redesign contextually-responsive teacher preparation around $21^{\text {st }}$ century competencies rather than attempting to integrate these competencies into an existing traditional framework. TLLSC re-envisions teacher preparation through purposeful, mutually beneficial instructional partnerships (Kruger, 2009) that fit the needs of schools and communities and increase the number of skilled educators who are committed to and capable of teaching diverse populations. Grounded in a practice-based theory of professional learning (Ball \& Cohen, 1999) and research-based understandings about schooluniversity partnerships (Carroll, 2006) and student learning (Kruger, 2009), this model exemplifies a systemic and ecological approach (Zeichner, 2006) to the transformation of university-based programs by 
recognizing the multiple and varied contexts that shape teacher preparation, including local, state, and national policies.

The development of TLLSC began with a break from the restrictive model defined by course credit hours and certification levels, as well as from traditional foundations-methods-clinical models (involving university-based coursework followed by clinical experiences). As a result, TLLSC utilizes a four-year continuum of extended field experiences which include faculty-guided learning modules and professional learning communities (PLCs) to develop and deepen the enduring understandings, knowledge, skills, and dispositions of resilient and effective early childhood teachers. Figure 1 illustrates the universal foundational concepts upon which TLLSC was developed. The teacher candidate is represented inside a large sphere of potential influence; each semester applies layers of experience in teaching, learning, and leading, deepening candidates' knowledge and skills within education settings and communities. Over time, this relationship becomes transactional, with candidates expanding their influence within the same community contexts that nurture their development as teachers.

\section{[insert Figure 1 here]}

This program does not simply involve surface level redesign to the content and sequencing of course offerings, or an increased emphasis on clinical work within an existing program; rather, it represents a transformation in the way that university-based teacher preparation is conceived.

Specifically, nearly all coursework has been replaced with a continuum of field experiences designed to guide novice early childhood teacher candidates to mastery of effective practice over four years. This stems from a shared belief among faculty and community partners that teacher candidates need extensive opportunities to work alongside expert early childhood professionals and program faculty in high-need, high performing urban settings. Schools and community organizations shared in the mission to build authentic, mutually beneficial partnerships in which collaborative decision-making 
benefits all partners (Kruger, 2009). Deep, purposeful collaboration with partner schools and organizations has ensured that candidates gain rich experience in engaging with diverse populations, including students with special needs and those labeled as ELLs. Furthermore, this new shared context for teacher education allows for measures of program effectiveness to shift in focus from graduation/program completion to performance assessment of the degree to which faculty and candidates meet the needs and address the priorities of families, schools, and community agencies.

[Insert Figure 2 around here.]

Depicting the re-envisioning of early childhood teacher preparation through the TLLSC model, Figure 2 introduces eight interrelated themes of this redesign. Each row represents a theme as a continuum, with traditional university-based teacher preparation on the left and the shared aims of TLLSC on the right. These themes include role redefinition for teacher candidates, university faculty, and partner schools and organizations. Rather than learning about teaching at the university and applying that knowledge in clinicals and student teaching, candidates now learn alongside faculty and practicing professionals through guided apprenticeship. Rather than adhering to a university course calendar and taking place in the college classroom, candidates' experiences in teacher preparation follow a sequence designed to facilitate exploration, specialization, and then mastery of knowledge and skills within the contexts of early childhood education: school, center, community, and home. Faculty members serve as mentors, facilitating experiences in teaching and learning in collaboration with early childhood professionals. This stands in contrast to traditional approaches in which faculty teach university courses, with clinical supervisors serving as a link between university and cooperating sites. Here, early childhood professionals serve as co-teacher educators, collaborating with faculty to build and support candidate knowledge, skills, and dispositions. Faculty guide candidates through semester-long field experiences, facilitating formal PLCs designed to build candidates' reflective practice and the resilience associated with effective teaching. As a result, the 
definition of program success expands beyond teacher certification and employment to include evidence of an impact on children and families in diverse communities.

Within the Early Childhood Special Education (ECSE) strand of the TLLSC program, candidates spend sequences 4 through 8 in the settings of early childhood education, with community partners offering a variety of experiences within inclusive and family-centered program models emphasizing best practices for young children, including DEC’s Personnel Standards (2014) and Recommended Practices (Sandall et al., 2005) for Early Intervention and Early Childhood Special Education. A sampling of the ECSE community partners includes: (a) Early Head Start and Early Intervention providers in sequence 4, (b) inclusive preschool programs with both ELLs and children in ECSE in Sequences 5, 6, and 8, and (c) inclusive early elementary settings in several private and public settings in sequences 6 and 7. Faculty and partners at these institutions collaborate to ensure that candidates receive the benefit of modeling, mentorship, and guided practice in inclusive practices across broad spectrums of age and special needs.

\section{Intersections of Teacher Education and Early Childhood Education}

TLLSC resides in the intersection of early childhood and teacher education and resulted from collaboration among faculty and community stakeholders in both areas. All teacher candidates preparing to teach in B-12 settings follow a universal continuum in the redesigned program. The TLLSC continuum consists of eight full semester-long sequences of field experiences, each of which is divided into shorter modules addressing key universal themes and competencies. These, in turn, are adapted for each major, and supplemented by additional sequences as presented in Figure 3. Candidates begin TLLSC in their first semester as freshmen and transition into an area of specialty following sequence 3 . This eliminates the need for education core requirements from sequence 4 on, allowing for additional credit hours in the ECSE major which are used to achieve the integration of 
additional teaching endorsements but also leave room for subsequent adaptations in response to changing credentialing requirements.

[Insert figure 3 here]

The initial decision to develop a universal program continuum for all B-12 candidates provided a natural context for discussions of the intersection of teacher education and early childhood education. For example, discussions about the importance of meaningful early field experiences for candidates interested in working with young children led faculty to draw the conclusion that all teacher candidates must experience the full developmental continuum from B-12 to better understand the needs of children at each age, gain experience in the transitions between levels of service delivery, and gain a fuller understanding of the relationship between developmentally appropriate practice and differentiated instruction. These experiences also better informed their choice of an area of specialty. As a result, sequences one through three in the universal continuum include field-based learning modules at each of these levels.

After sequence three, candidates select an area of specialty (i.e., early childhood, elementary, secondary, special education); at this point, for example, early childhood teacher candidates transition into birth-to-age- 8 settings for sequences four through eight. Within sequences 4 through 6, candidates are evaluated by faculty, co-teacher educators, and peers not only through the artifacts of their planning and child assessment, but through observation and analysis of video recorded teaching vignettes as well. Over these sequences, a community of reflective practice is emphasized so that candidates grow increasingly confident in reflecting and providing feedback, some of which is directly aligned with the edTPA Evaluation of Teaching Practice (part of the state-mandated culminating program assessment completed during student teaching). They incorporate this feedback into their practice so that, upon reaching sequence 7, they develop a pilot of edTPA (which 
also requires video recorded teaching vignettes) that is based in students' needs, with minimal disruption to their role as co-teacher during the final one-year internship.

A focus on families and communities created another point of overlap in the program redesign process. Early childhood professional preparation standards (e.g., NAEYC, 2009) concerning collaboration with families aligned seamlessly with extended modules focused on understanding and addressing the needs of families and communities through supervised work in community agencies and schools. These modules take place for all candidates in sequence 2 , and are strongly emphasized throughout sequences 4 through 8 for early childhood majors (particularly in modules focused on early intervention for families of infants and toddlers with special needs). Finally, state requirements for early childhood teachers influenced the decision to integrate the ESL endorsement into the early childhood teacher education program. However, this decision was expanded to include all candidates, so that all B-12 candidates now receive the necessary preparation to earn an ESL endorsement, targeted and integrated across the program continuum.

Integrated preparation leading to an endorsement in early childhood special education was retained and redesigned; as a result, graduates of the early childhood TLLSC program now enter the field as educators fully credentialed in all of the areas formally recognized by the state of Illinois. Identifying these areas of overlap facilitated the design of a program which allows candidates to graduate with a teaching license in early childhood education, endorsements in ECSE and ESL, and the coursework and field experiences necessary to secure initial credentialing as an early intervention provider in developmental therapy. Beyond qualifying for these credentials, candidates enter the field as early childhood professionals, mentored in each setting under the supervision of faculty and coteacher educators collaborating as members of site-based PLCs devoted to reinforcing the links between theory, practice, and evidence. These candidates are thus positioned to meet the need for 
highly qualified, fully credentialed professional early educators who can meet $21^{\text {st }}$ century needs within the contexts of schools and communities.

\section{Points of Collaboration across Preparation Programs}

Early childhood and K-12 teacher education must aim for collaborative reflection and innovative planning, and responsive programming, rather than isolated points of refinement to traditional teacher preparation. In the case of TLLSC, this collaboration was fueled by (a) alignment of vision and supportive program and university leadership, (b) shared positioning in the community, (c) a focus on an understanding the developmental continuum, (d) practices to support

cultural and linguistic diversity and special needs, and (e) a collective mission of measurable positive impact on children, families, schools, and communities. To begin the collective conversation, teacher preparation faculty examined existing areas of overlap and alignment across B-12 teacher education. During the TLLSC design process, three conclusions emerged that paved the way for and sustained deeper collaboration over time. Not only did these conclusions serve the TLLSC program redesign effort and improve the overall program, but they also led to greater representation of the philosophy, standards, settings, and voice of early childhood education in the collaboration process:

\section{Collaborative frameworks must allow for meaningful contributions from teacher}

education faculty at every level. Informed by $21^{\text {st }}$ century competencies in early childhood and K12 education (AACTE, 2010), partners utilized backward design (McTighe \& Wiggins, 2005) to plan TLLSC. In work groups, faculty spent one year developing and defining universal enduring understandings of effective educators, followed by related knowledge, skills, and dispositions, to serve as the foundation of teacher education programs at every level in both general and special education. Community partners collaborated with faculty in designing and sequencing field-based modules that addressed these areas. Backward design allowed for integration of knowledge and skills related to global perspectives, ELLs, special needs, and literacy in within every academic major. 
Infused into the early childhood education program, these themes made possible the integration of all available educator credentials into the B.S.Ed. degree (including early intervention credentialing). Backward design served the early childhood teacher education program by reinforcing the systematic integration of preparation for these additional credentials throughout the resulting program. This, in turn, later allowed for seamless integration of multiple early childhood professional preparation standards and a program that is highly specialized and comprehensive rather than generalist.

\section{Acknowledgement of efforts in the field of early childhood to specifically address $21^{s t}$} century competencies provides a context for exploring overlap. AACTE (2010) designed the $21^{\text {st }}$ century competencies with early childhood education in mind. The five primary areas for teacher preparation redesign efforts (i.e., standards, assessment, curriculum and instruction, professional development, and learning environments) are universal, applicable across birth-to-age-3, preKindergarten, and early elementary education, and are emphasized across early childhood professional preparation standards. Furthermore, an examination of the NAEYC's (2009) professional preparation standards highlight many examples of opportunities to emphasize critical thinking, communication, collaboration, and creativity. Not only are these essential skills central foci of early education and cited by kindergarten teachers as a source of early school difficulty (Denham et al., 2012), but they are competencies of effective early childhood educators as well. Within the TLLSC design process, these competencies facilitated the design of universal modules that meet diverse individual programmatic needs.

K-12 and early childhood teacher preparation programs both must (a) promote the use of evidence-based best practices, (b) promote linkages between research, theory, and practice, (c) address the continuum of young children's abilities and needs, (d) ensure equal access by responding to diversity of culture, language, and ability, and (e) attend to the current context of teacher role and professional goals (AACTE, 2010; NAEYC, 2009). These collective themes provided a basis for 
exploring the overlap between teacher education and early childhood education and allowed for a common language to exist in cross-programmatic collaborative groups. This also facilitated the development of universal program outcomes that apply to teacher candidates at every level.

State policies regarding early childhood teacher certification directly reflect a commitment to preparing educators for growing diversity in Illinois. By 2014, early childhood educators who teach in preschool settings serving ELLs will be required to hold a bilingual or ESL teaching endorsement (Illinois \$23.111.235.20). This requirement places early childhood education teacher preparation firmly on the front line of addressing $21^{\text {st }}$ century competencies. A fully credentialed early childhood educator in states such as Illinois now, by definition, has knowledge, skills, and experience in addressing cultural and linguistic diversity. This reinforces bilingual education as a universal area of intersection in which early childhood teacher educators must play a role, particularly when innovations in teacher preparation are considered.

Early childhood special educators who work with diverse young children must align evidence-based practices in early intervention and early childhood special education (Odom \& Wolery, 2003), whether addressed in integrated programs or ECSE endorsement programs. They are, however, linked by recognition and deep respect for the fact that the primary environment in which young children's learning takes place is the home (McDonald et al, 2011; Murrell, 2000; Noel, 2010). Effective EI and ECSE practitioners must possess two sets of interrelated competencies. First, they must be skilled in accessing community resources to support families in meeting their children's needs. But they must also facilitate positive nurturing relationships between caregivers and their children (Lee, Ostrosky, Bennett, \& Fowler, 2003). These interrelated aims represent a key area of difference between the preparation of early childhood and K-12 educators, for whom teaching, and in effect teacher preparation, focuses primarily on working with children in classrooms (Odom \& Wolery, 2003). Meaningful involvement of families is an aspect of education essential to the goal 
of developing seamless continuums of support from B-12, and an objective of teacher preparation for which early childhood educators are uniquely qualified (Center for Study of Educational Policy, 2012). The universal aim in this redesign of addressing family and community needs provided an opportunity for early childhood faculty to provide this leadership.

\section{Core principles unique to early childhood teacher education can positively influence}

all teacher candidates. Organizations that inform early childhood teacher preparation (e.g., NAEYC, NCATE, DEC) and extant research on teacher characteristics and school quality suggest that early childhood teachers must possess significant knowledge of child development within a cultural context (Maude et al., 2009; Lee \& Johnson, 2007; Ryan \& Grieshaber, 2005). Developmentally appropriate practice (DAP) requires an understanding of the many varied influences on each child's development, which in turn informs the planning of learning environments and instructional practices that are respectful of children's and families' needs and interests (NAEYC, 2009). DAP rests upon the ability of professionals to observe, assess, and intervene with children across the developmental domains, at children's individual levels, and within the meaningful contexts of the home, daily routines, play, and structured learning experiences.

Both philosophically and in practice, DAP is linked to culturally and linguistically appropriate practice (Ryan \& Grieshaber, 2005), as well as to Universal Design for Learning (Rose \& Meyer, 2002) and the individualization of educational services that are integral to the delivery of special education services. Furthermore, the importance of knowledge of development and special needs is acknowledged by AACTE (2011) and K-12 professional standards (e.g., McLaughlin, \& Overturf, 2012). Still, the separation of preparation from practice, theory from application is sharply evident in instances where teacher education programs offer isolated foundational courses in human development and educational psychology. If developmental theory and its implications for practice are taught only in the context of foundational coursework, the opportunity is lost to meaningfully 
examine intersections of these concepts in early childhood, elementary, and special education practice with a goal of directly aligning developmental and theoretical principles with practice.

Isolation of foundational courses in (university name blinded for review)'s traditional preparation program was a direct target of the TLLSC redesign. Three key decisions within the redesign process had implications for exploring the intersections of early childhood, elementary, and secondary teacher preparation. First, the universal decision to eliminate university-based courses as the primary mode of instructional delivery had profound implications for the theory-to-practice gap. The resulting model, emphasizing field-based, faculty-mentored learning modules linked the observation, learning, and application of developmental and learning theory to practice. Next, a key feature of the redesign included exposure to a wide variety of schools and community-based settings during candidates' first three sequences. Noting the need for programs serving infants and toddlers opened a discussion of the importance of candidates experiencing and understanding the entire developmental continuum. This discussion resulted in a universal decision that all teacher candidates would participate in modules that provided direct experience with children at every level (infanttoddler, pre-K, elementary, middle, and secondary). Finally, a universal field-based learning module emerged from these discussions; in this module, candidates link learning developmental, and language theories to practice through a series of experiences at each developmental level with diverse children. This module now exposes all candidates to early childhood settings, theory, principles, and practice.

\section{Conclusions and Implications for Early Childhood Teacher Education}

Effective early childhood teacher education must be firmly grounded in the established theories and standards of early childhood education, but also well-positioned to meet the needs of diverse young children and to adapt to a context of increased accountability and demographic shifts. The impact of early childhood teacher education must be measured through the aims and goals of 
the settings in which young children live, grow, and are served, rather than solely through outcome measures of traditional teacher education (McDonald et al, 2012; Lucas et al, 2008; Valdes et al., 2005). These aims reinforce calls for fundamental change in teacher preparation that equips candidates with the skills they need to address $21^{\text {st }}$ century challenges.

Four-year, undergraduate teacher preparation is essential for the preparation of fully credentialed and well-prepared educators who not only meet state professional preparation standards, but understand a wider range of development, communicate effectively with educators of children at other levels, share roles and responsibilities, and adapt to the expectations of the diverse settings in which young children are served. In fact, early childhood is unique in its ability to achieve precisely this goal, which is aligned with NCATE's (2009) expectation that states more fully require utilization of existing early childhood teacher credentialing. Programs emphasizing a meaningful continuum of community-based learning are essential to producing a knowledgeable and highly skilled workforce ready to address these goals.

Early childhood education remains a field that suffers from inconsistencies in certification and licensing requirements, as well as systemic issues such as marginalization and undercompensation of educators. As a result, TLLSC serves not as the prototype for all early childhood teacher preparation, but an example illustrating the degree to which teacher educators may revisit and rethink their approaches to preparing teachers to meet these needs. The challenges associated with accomplishing this goal may be greater in early childhood than in any other area of teacher preparation, given great diversity within the profession, inconsistencies in professional preparation, and the disconnection of early childhood teacher preparation from the larger teacher education discourse. TLLSC began with conversations about the fundamental similarities and differences across the levels of teacher preparation in order to address research to practice and university school gaps, and strengthened the view of (name blinded for review)'s teacher preparation 
faculty that education must aim to create a continuum of supports from B-12. Under supportive leadership, these conversations grew into a unified effort to develop redesign mechanisms that benefitted all programs. Through this type of commitment to exploring deeply the areas of intersection among teacher preparation programs, early childhood teacher educators may strengthen their voice in $21^{\text {st }}$ century teacher education discourse and contribute to innovation demonstrating that candidate enter early childhood settings as skilled, resilient professionals who have already proven their ability to positively influence children, families, and communities. 


\section{References}

American Association of Colleges for Teacher Education. (2011). Preparing general education teachers to improve outcomes for students with disabilities. Retrieved May 16, 2013 from http:/ /www.aacte.org.

American Association of Colleges for Teacher Education. (2004). The early childhood challenge: Preparing high-quality teachers for a changing society. Retrieved August 1, 2012 from http://www.aacte.org.

American Association of Colleges of Teacher Education (2010). 21 st century knowledge and skills in educator preparation. Retrieved August 1, 2012 from http://www.aacte.org.

Authors (2013). Removed for blinded review.

Ball, D., \& Cohen, D. (1999). Developing practice, developing practitioners: Toward a practicebased theory of professional education. In L. Darling-Hammond \& G. Sykes (Eds.), Teaching as the learning profession (pp. 3-32). San Francisco, CA: Jossey-Bass.

Brown, C. P., \& Feger, B. (2010). Examining the challenges early childhood teacher candidates face in figuring their roles as early educators. Journal of Early Childhood Teacher Education, 31(4), 286-306.

Carroll, D. M. (2007). Developing joint accountability in university-school teacher education partnerships. Action in Teacher Education, 27 (4), 3-11.

Certo, J. (2006). Beginning teacher concerns in an accountability-based testing environment. Journal of Research in Childhood Education, 20, 331-349.

Center for the Study of Education Policy (2011). From birth to graduation and beyond: Aligning best practices in educational systems to improve learning outcomes. Retrieved July 1, 2013 from http:// centereducationpolicy.illinoisstate.edu.

Chandler, L. K., Cochran, D. C., Christensen, K. A., Dinnebeil, L. A., Spino, M., Gallagher, P. A., Lifter, K., \& Stayton, V. D. (2012). The alignment of CEC/DEC and NAEYC personnel preparation standards. Topics in Early Childhood Special Education, 32(1), 52-63.

Cochran-Smith, M. (2004). The problem of teacher education. Journal of Teacher Education, 55, 4, 295299.

Cole, D. J., \& Ryan, C. W. (2001). Building \& assessing school partnerships: The Wright State model. ERIC document.

Darling-Hammond, L. (2006). Powerful teacher education: Lessons from exemplary programs. San Francisco, CA: John Wiley \& Sons. 
Darling-Hammond, L., \& Baratz-Snowden, J. (Eds.). (2007). A good teacher in every classroom: Preparing the highly qualified teachers our children deserve. Educational Horizons, 85(2), 111-132.

Demma, R. (2010). Building ready states: A governor's guide to supporting a comprehensive, high-quality early childhood state system. Retrieved July 21, 2013, from www.nga.org.

Denham, S. A., Bassett, H. H., Way, E., Mincic, M., Zinsser, K., \& Graling, K. (2012). Preschoolers' emotion knowledge: Self-regulatory foundations, and predictions of early school success. Cognition \& Emotion, 26(4), 667-79.

Division for Early Childhood. (2014). Personnel standards for early intervention and early childhood special education. Retrieved January 27, 2014, from http://www.dec-sped.org.

Division for Early Childhood. (2010). Position statement: Responsiveness to ALL children, families, and professionals: Integrating cultural and linguistic diversity into policy and practice. Retrieved August 29, 2012, from http:/ /www.dec-sped.org.

Early, D. M., Maxwell, K. L., Burchinal, M., Alva, S., Bender, R. H., Bryant, D., et al. (2007). Teachers'education, classroom quality, and young children's academic skills: Results from seven studies of preschool programs. Child Development, 78, 558-580.

Early, D. M., \& Winton, P. J. (2001). Preparing the workforce: Early childhood teacher preparation at 2- and 4-year institutions of higher education. Early Childhood Research Quarterly, 16 (3), 285-306.

Feistritzer, E. C. (2007). Alternate routes to teaching. Upper Saddle River, NJ: Prentice Hall.

Fuligni, A.S., Howes, C., Lara-Cinisomo, S., \& Karoly, L. (2009). Diverse pathways in early childhood professional development: An exploration of early educators in public preschools, private preschools, and family child care homes. Early Education and Development, 20(3), 507-526.

Hardman, M. L., \& Teacher Education for Inclusive Education. ( 2009). Redesigning the preparation of all teachers within the framework of an integrated program model. Teaching and Teacher Education, 25, 4, 583-587.

Hatch, J. A., \& Benner, S. M. (2009). From the editors: Positionings and possibilities for early childhood teacher education. Journal of Early Childhood Teacher Education, 30, 91-92.

Hollins, E. R. (2011). Teacher preparation for quality teaching. Journal of Teacher Education, 62(4), 395407. 
Hollins, E., \& Guzman, M.T. (2005). Research on preparing teachers for diverse populations. In M. Cochran-Smith and K.M. Zeichner (Eds.), Studying teacher education: The report of the AERA Panel on research and teacher education (pp. 477-548). Mahwah, NJ: Lawrence Ehrbaum Associates.

Kruger, T. (2009). Effective and sustainable university-school partnerships : Beyond determined efforts by inspired individuals. Canberra, Australia: Australian Institute for Teaching and School Leadership.

Larabee, D. (2010). Teach for America and Teacher Ed: Heads they win, tails we lose. Journal of Teacher Education, 61, 48-55.

Leatherman, J. M., \& Niemeyer, J. A. (2005). Teachers' attitudes toward inclusion: Factors influencing classroom practice. Journal of Early Childhood Teacher Education, 26(1), 23-36.

Lee, K., \& Johnson, A. (2007). Child development in cultural contexts: Implications of cultural psychology for early childhood teacher education. Early Childhood Education Journal, 35, 3, 233-243.

Lee, H., Ostrosky, M. M., Bennett, T., \& Fowler, S. A. (2003). Perspectives of early intervention professionals about culturally-appropriate practices. Journal of Early Intervention, 25(4) 281-295. Lim, C. I., Maxwell, K. L., Able-Boone, H., \& Zimmer, C. R. (2009). Cultural and linguistic diversity in early childhood teacher preparation: The impact of contextual characteristics on coursework and practica. Early Childhood Research Quarterly, 24, 1, 64-76.

Macy, M., Squires, J. K., \& Barton, E. E. (2009). Providing optimal opportunities: Structuring practicum experiences in early intervention and early childhood special education preservice programs. Topics in Early Childhood Special Education, 28(4), 209-218.

Maude, S. P., Hodges, L., Brotherson, M., Hughes-Belding, K., Peck, N., Weigel, C., \& Sharp, L. (2009). Critical ref lections on working with diverse families: Culturally responsive professional development strategies for early childhood and early childhood special educators. Multiple Voices For Ethnically Diverse Exceptional Learners, 12(1), 38-53.

McDonald, M., Tyson, K., Brayko, K., Bowman, M., Delport, J., \& Shimomura, F. (2011). Innovation and impact in teacher education: Community-based organizations as field placements for preservice teachers. Teachers College Record, 113(8), 1668-1700.

Meisels, S. (November 29, 2011). Common Core standards pose dilemmas for early childhood. Retrieved August 1, 2012, from http://www.washingtonpost.com

McLaughlin, M., \& Overturf, B. J. (2012). The Common Core: Insights into the K-5 standards. The Reading Teacher, 66(2), 153-164. 
Moll, L. C. \& Gonzalez, N. (1997) Teachers as social scientists: Learning about culture from household research. In Hall, P. (Ed.). Race, Ethnicity, and Multiculturalism: Policy and Practice. New York: Routledge.

Murrell, P.C., Jr. (2000). Community teachers: A conceptual framework for preparing exemplary urban teachers. The Journal of Negro Education, 69 (4), 338-348.

National Association of Early Childhood Teacher Educators (2009). NAECTE position statement on early childhood certification for teachers of children 8 years old and younger in public school settings. Journal of Early Childhood Teacher Education, 30(2), 188-191.

National Association for the Education of Young Children (2009). Developmentally appropriate practice in early childhood programs serving children birth through age 8: A position statement. Retrieved September 1, 2013 from http://www.naeyc.org

National Association for the Education of Young Children (2009). Where we stand on professional preparation standards: A position statement. Retrieved August 1, 2012 from http:/ /www.naeyc.org

National Association for the Education of Young Children and National Association of Child Care Resource and Referral Agencies (2011). The early childhood education professional development training and technical assistance glossary. Retrieved August 1, 2012 from http://www.naeyc.org

Noel, J. (2010). Weaving teacher education into the fabric of urban schools and communities. Teacher Education Quarterly, 37(3), 9-25.

Odom, S. L., \& Wolery, M. (2003). A unified theory of practice in early intervention/early childhood special education: Evidence-based practices. Journal of Special Education, 37, 3, 164-173.

Partnership for $21^{\text {st }}$ Century Skills. (2010). Framework for $21^{\text {st }}$ century learning. Retrieved on August 1, 2012, from http://www.21stcenturyskills.org.

Recchia, S.L., Beck, L., Esposito, A., \& Tarrant, K. (2009). Diverse field experiences as a catalyst for preparing high quality early childhood teachers. Journal of Early Childhood Teacher Education, 30(105122).

Rose, D. H., \& Meyer, A. (2002). Teaching every student in the digital age: Universal Design for Learning. Alexandria, VA: ASCD.

Rust, F. (2010). Shaping new models for teacher education. Teacher Education Quarterly, 37(2), 5-18.

Ryan, S., \& Grieshaber, S. (2005). Shifting from developmental to postmodern practices in early childhood teacher education. Journal of Teacher Education, 56(1), 34-45. 
Sandall, S., Hemmeter, M.L., Smith B.J., \& McLean, M.E. (Eds.) (2005) DEC Recommended practices: A comprehensive guide for practical application in early intervention/early childhood special education. Missoula, MT: Division for Early Childhood.

Wrigley, T. (2000). The Power to Learn: Stories of Success in the Education of Asian and Other Bilingual Pupils. Staffordshire, England: Trentham Books Limited.

Zeichner, K. (2010). Rethinking the connections between campus courses and field experiences in college- and university-based teacher education. Journal of Teacher Education, 61(1-2) 81-99. 